Review Essay

\title{
New Directions for the History of Aviation
}

\author{
Dominick A. Pisano
}
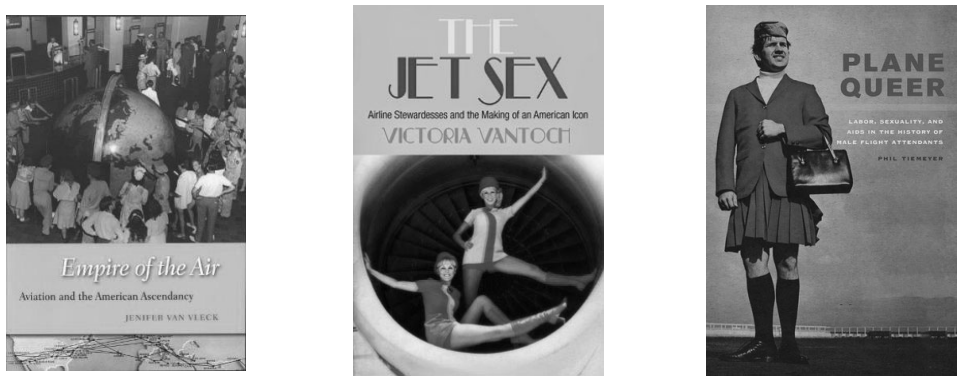

EMPIRE OF THE AIR: Aviation and the American Ascendancy. By Jenifer Van Vleck. Cambridge, MA: Harvard University Press. 2013.

THE JET SEX: Airline Stewardesses and the Making of an American Icon. By Victoria Vantoch. Philadelphia: University of Pennsylvania Press. 2013.

PLANE QUEER: Labor, Sexuality, and AIDS in the History of Male Flight Attendants. By Phil Tiemeyer. Berkeley: University of California Press. 2013.

\section{Introduction}

The books under consideration here might justifiably be termed products of the "New Aerospace History." This was a term coined by my colleague at 


\section{Dominick A. Pisano}

the National Air and Space Museum, Smithsonian Institution, Washington, DC, Roger Launius, to characterize what he believed was a "significant transformation that has been taking place in the field since the 1980s. Specifically, the New Aerospace History is intrinsically committed to relating the subject to larger issues of society, politics, and culture, taking a more sophisticated view of the science, technology, and individual projects than historians previously held. In the past, many writers on aerospace history held a fascination with the machinery, which has been largely anthropomorphized and often seen as "magical."'1

Launius goes on to suggest a typology for the history of space exploration. Aerospace history should neither be celebratory nor should it be used "to attack the whole enterprise." Among the legitimate inquiries that historians of space exploration should make are those that relate to the origins of the space age; civil-military relations in space; national sovereignty in space exploration; the politics of space exploration; space flight and its technological legacy; the human imperative in space exploration; space and popular culture. Indeed, all of these typological components could be applied directly to the study of what might be termed "aero" history (the initial component of the term "aero-space history), or what is known simply as the history of aviation. ${ }^{2}$

Aerospace history, in many respects a branch of the history of technology, has thus become caught up in a larger movement of historical studies about technology. One of these was the Social Construction of Technology (SCOT), first posited by Wiebe E. Bijker, Thomas Hughes, and Trevor Pinch in The Social Construction of Technological Systems (Cambridge: Massachusetts Institute of Technology Press, 1989; Anniversary Ed., 2012). The original conception of SCOTS included the study of Large-Scale Technological Systems (LTS) and Actor-Network Theory (ANT), prevalent in what has become known as Science and Technology Studies (STS).

These endeavors sought to move away from what is termed "technological determinism," or, in its most simplistic terms, the idea that technology has a progressive inevitability that is beyond human agency. The editors believed that "whether questioning the fixed boundary between humans and nonhumans, or paying attention to the nontechnical aspects when studying the history of technical systems - all three approaches embraced the methodological principle of paying attention to how the borders between the social and the technical were drawn by actors, rather than assuming that these borders are pre-given and static. This also brings out the common element of a constructivist perspective. Rather than taking an essentialist view of technologies and their contexts, we all agreed that describing the activities of actors - whether in the form of relevant social groups (SCOT), systems builders (LTS), or actants (ANT) — was more interesting than a promethean history of technology that emphasized how heroic inventors and engineers stole great ideas about technology from the gods and gave them to mere mortals." 3

Another prevalent direction for aerospace history has been cultural history in its multiplicity of meanings. In their introduction to The Cultural Turn in U.S. 
History: Past, Present and Future, the editors, James W. Cook and Lawrence B. Glickman, put forth a number of propositions for a history of the cultural history of the United States. Among the most relevant for our purposes here is "Proposition Three: More recent varieties of U.S. cultural history have regularly encompassed a wide range of "culture concepts.",

These "culture concepts" are six in number: (1) Culture Defined as Artistic Expression; (2) Culture Defined as the Larger Matrix of Commercial Institutions and Structures in Which Artistic Forms are Produced; (3) Culture Defined as Any Social or Institutional Sphere in Which Collective Forms of Meaning are Made, Enforced, and Contested; (4) Culture Defined as a Common Set of Beliefs, Customs, Values, and Rituals - a.k.a. the Anthropological Concept of Culture; (5) Culture Defined as a Semiotic or Discursive System; (6) Culture Defined as Transnational or Global Circulation. Other relevant propositions for our purposes here are "Proposition Eight: The unifying trope of a 'cultural turn' needs to be understood not as the evolution of a single method but as a weaving together of innovations from a variety of disciplinary locations," and "Proposition Ten: Over the past three decades, many US cultural historians have developed new understandings of politics as central components of their methodological projects." Finally, also pertinent is "Proposition Twelve: As cultural history has moved to the center of the discipline, the question of what is and what is not cultural history has become increasingly complex."4

All of these approaches have validity, even though we must keep in mind the caveat put forth by Cook and Glickman for cultural history, which in my estimation is applicable to proponents of a particular type of aerospace history or to the history of technology in general; i.e., that as aerospace (or "aero-space," if one believes that the two areas are separate and distinct) history becomes more central, the question of what it is and what it is not becomes increasingly complex and bewildering. Thus, the three books under review are difficult to categorize; suffice it to say that they encompass diplomatic history but with a technological twist (Van Vleck) and aspects of social and cultural history, in that they explore gender, sexuality, and labor history (Vantoch and Tiemeyer).

\section{Aerial Empire and Its Attendant Cultural Issues}

Jenifer Van Vleck's Aviation and the American Ascendancy is the cornerstone of the three works. In her introduction, Van Vleck argues that, "viewing technology as central to the history of international relations in the twentieth century, this book integrates aviation into a growing body of scholarship on what has been called 'the new global history,' or history after 'the transnational turn.' This book has rightly critiqued, and worked to rescind, what Thomas Bender described as 'the unexamined assumption that the nation was the natural container and carrier of history.' Yet in advocating the globalization of history without historicizing globalization, historians risk simply replacing the nation with the world as history's new naturalized container. For the global is not the blank canvas upon 
which history unfolds, but a historically constituted category in its own right." Van Vleck goes on to explain that her book sets out to analyze how the ideal of a global American aerial empire became not only "thinkable" but possible in a time of great idealism about the airplane and its ultimate role as an arbiter of the role the United States would play on the international stage.

The airline most representative of this global outreach was, of course, Pan American Airways, the first American carrier to reach into Central and South America, and later to establish routes across the Atlantic and Pacific Oceans, and who thought of themselves as the "Chosen Instrument" for overseas operations; i.e., "a private corporation officially authorized to implement state policy objectives." However, the global outreach idea was not limited to Pan American (69).

The United States did not think there was a limit to the conception of commercial aviation as an instrument of diplomatic and cultural supremacy, but they soon found out that other countries, namely Great Britain and the Soviet Union, had other ideas. Nevertheless, the "Open Sky" policy, crafted by New Deal insider and "Brains Trust" leading light Adolph Berle, "elevated the United States' position in the emerging postwar world, facilitating a larger, gradual transformation from Pax Britannica to Pax Americana, from an international order structured in the geopolitical idiom of territorial empire to one structured in the geoeconomic idiom of capital and markets." In the post-World War II era, the aviation industry helped bring about the overwhelming expansion of American economic power and the military power necessary to sustain it. Van Vleck explains that this political phenomenon spilled over into the cultural sphere, where aviation became the symbol not only of the interests of the United States, but of the world (195-96).

While other countries challenged those ideas, the international skies were happy skies for the United States in the postwar period. But, as Van Vleck points out in chapter seven, "The Jet Age and the Limits of American Power," there were limits to American aerial hegemony. Despite the optimistic, and indeed imperialist (in an economic sense) and naïve outlook for pre- and immediate postwar American commercial aviation, everything did not proceed according to plan.

In an especially cogent comment, Van Vleck writes that "when President Jimmy Carter signed the Airline Deregulation Act of 1978, he struck a fatal blow to the midcentury corporatism that had allowed otherwise unprofitable companies to thrive as subsidized 'chosen instruments."' Reorganized around neoliberal principles, the US airline industry split into a multitude of smaller companies, none of which could claim to be the American flag carrier, as Pan Am had been for half a century. Deregulation not only changed the economic rules of the game; it transformed the very meaning of air travel. Aviation had ceased to carry with it the empire-building "transcendent cultural significance" of the past, and it became just another corporate enterprise" (280).

Vantoch and Tiemeyer provide a convenient jumping-off place for discussions of deeper, perhaps more imbedded, cultural ideas and ideals in the history of commercial aviation, but certainly relate to Van Vleck's notion of American aerial hegemony. For while proponents - political, diplomatic, corporate - saw 
commercial aviation as a way to reach transcendence in American political, economic, and military affairs, the reality was that many of the human problems and situations that routinely take place on earth were routinely transferred to the airplane's cockpit and cabin, and these mainly had to do with gender, sexuality, labor, and even illness.

Victoria Vantoch's Jet Sex: Airline Stewardesses and the Making of an American Icon is a study of how American stewardesses (Vantoch prefers the term "stewardess" to the one currently in favor, the less gender-specific "flight attendant") in the Cold War era became symbols of American culture. (In that regard, they appear to be the human face of Van Vleck's American aerial empire, what Vantoch calls "the typical American girl.") Vantoch, in fact, argues that American stewardesses represented Cold War ideas and ideals of femininity, beauty, and glamour, and that these ideals could be exported to other places around the globe. Vantoch thus expands on the ideas presented by Van Vleck, arguing that with the Cold War as context, the stewardess became in effect part of America's aerial empire, and her "gender, sexuality, and beauty" became integrated into international politics. The image of the beautiful American stewardess was even pitted against representations of Soviet women in the same profession as inferior and unglamorous. Accordingly, the American stewardess was used to justify American political, military, and economic hegemony (Vantoch, 7-8). ${ }^{5}$

In the dominant thinking of the Cold War era, the "typical American girl" had to be between twenty-one and twenty-six years of age, unmarried, from 5'3" to 5' 6" tall, weigh no more than 125 lbs., and be of the white race. Soon, however, these concepts of ideality came to be challenged in cases argued before the Equal Employment Opportunity Commission (EEOC) and in the courts. At the same, time, however, Vantoch notes that the ideal stewardess underwent another transformation into overt sexual object. These changes, Vantoch explains, came about for numerous reasons, including trends in the advertising industry, the often tense relationship between Madison Avenue and airline executives, the rise of the jumbo-jet commercial aircraft and the expanding international travel market, and perhaps most important, the advent of cultural shifts in American life during the 1960s, such as the emphasis on the youth counterculture and the sexual revolution $(29,185)$.

Nevertheless, this trend disappeared with the advent of airline deregulation, which, Vantoch says, "would have a massive impact on the industry and on stewardesses' role in it. Dozens of small airlines surfaced around the country. In this intensely competitive new world of aviation many airlines would file for bankruptcy; several would recover after corporate restructuring. Some of the nation's biggest players would ultimately go out of business. In this new business atmosphere, airlines no longer had to out-sex their rivals - they could now compete primarily on the basis of cheaper fares." Vantoch argues that by the early 1980s, "no-frills service became the norm" and glamour, which had been a staple of the airline stewardess profession and a way of attracting travelers, no 


\section{Dominick A. Pisano}

longer had any meaning (212).

Phil Tiemeyer's Plane Queer: Labor, Sexuality, and AIDS in the History of Male Flight Attendants deals with what the author calls "the undulations of tolerance and discrimination experienced by male flight attendants from the dawn of commercial aviation in the late 1920s through the post-AIDS crisis years of the late 1990s and 2000s." Through the lens of the male steward $\backslash$ flight attendant, Plane Queer traces the development of sexism and homophobia in the American workplace and in legal proceedings during the twentieth century. These men were historically the first to be hired for the profession and who were at the time preferred to women. Gradual prejudice against male flight attendants that developed as a result of the suspicion that members of the profession were predominantly gay caused them almost to disappear. Nevertheless, male flight attendants advocated and pioneered labor practices in the airline industrysexual privacy rights; upholding the rights of HIV-positive employees; granting domestic partner benefits - that are now widely accepted in corporate America (Tiemeyer, 7).

Tiemeyer explains his use of the term "queer" in a persuasive fashion. "I use the term queer in this book," Tiemeyer writes, "even as I recognize it is fraught with potential for misunderstanding. The most helpful aspect of the term is that it implies a twofold transgression: one is 'queer' when one transgresses established gender norms, as in the case of transgendered individuals or, more aptly for my project, when one assumes social roles that belong to the other gender. Additionally, queer refers to homosexuality. In the case of male flight attendants, this dual significance is especially helpful: all male flight attendants were gender queers in that they were performing a job that was women's work." Because a "disproportionately high percentage were also gay," this made them also queer in the sexual sense (227n2).

Central to the book's arguments are the legal arenas in which the rights of male flight attendants were determined. In 1954, William Simpson, an Eastern Air Lines flight steward who was homosexual, was shot to death in Miami. Simpson had been lured to his death by two men who had a history of predatory behavior toward homosexuals. Facing a first-degree murder charge, the defendants' lawyers used the "Homosexual Panic" defense (i.e., that Simpson's killers were acting in self-defense), and the two men were convicted of the lesser crime of manslaughter. After Simpson many airlines, sensing the homophobic current in American culture at the time, prohibited the hiring of males.

Subsequently, two significant cases - Celio Diaz and Roderick McNeilpaved the way for males to return to the airlines. Diaz first took his case against Pan American Airways to the EEOC, but was unable to resolve it through arbitration. He then turned to the legal system, bringing a class action suit in the United States District Court for the Southern District of Florida. Using Section 703 of the 1964 Civil Rights Act as the basis of his case, he charged that Pan Am had violated his rights by refusing to employ him on the basis of his gender. The court The Diaz case, unfortunately, was not the end of discrimination against 
male flight attendants. Tiemeyer writes: "While flight attendants in the 1950s and 1960s had fought for a modicum of unofficial gay tolerance and the 1970s offered the first prospects of a fuller gay acceptance, the 1980s saw a retrenchment of exclusionary policies and growing social fears directed at these men because of AIDS" (136-37). Thus the physical and political struggles of male flight attendants symbolized the efforts of the entire gay community to overcome public fear and scapegoating by politicians.

Tiemeyer points to the case of Gaëtan Dugas, an Air Canada homosexual male flight attendant, who, as a result of Randy Shilts' bestselling book And the Band Played On: Politics, People, and the AIDS Epidemic, was branded "Patient Zero," the man whose widespread sexual adventuring on several continents brought the AIDS virus to America. As it turns out, the "Patient Zero" legend was bogus, but Dugas became a convenient scapegoat for homophobes. The entire "Patient Zero" story, as Tiemeyer points out, "reinforced for the public that men who engaged in anal sex and cavorted in bathhouses not only were more immoral but also invited plague-like diseases on themselves and the rest of society" (169). In the face of much evidence to the contrary, the public will to manufacture the Patient Zero mythology and use it as the cause of the AIDS epidemic in the United States demonstrated how ill at ease Americans were with the freedoms gays had won after the Stonewall riots of $1969 .^{7}$

The furor over Dugas once again threatened male flight attendants' right to work. One man, Gär Traynor, was removed by his employer, United Airlines, after he was diagnosed with AIDS in 1982. Traynor, and other male flight attendants from United who had been grounded, took their case to the courts. Traynor won back his right to work by arbitration, and as Tiemeyer notes, "his victory before an independent arbiter was a sort of dry run for these future cases, complete with expert testimony and a full cadre of lawyers. At the time, the ruling required that United treat its flight attendants with AIDS the same as those with other life-threatening illnesses, like cancer or epilepsy" (155). The Traynor decision extended to Persons with AIDS (PWA) in other workplace settings and enabled them to keep their jobs and maintain financial independence.

\section{Conclusions}

All three of these books resonate with what much of the "New Aerospace History" and, indeed, with what the social and cultural approaches to the history of technology mentioned above have in common; i.e., a pessimism (or, at the least, a healthy skepticism) about aviation technologies as a way of securing America's place in the world or as a form of transcendence. This is a far cry from the players in Van Vleck's narrative, for example, who believed that aviation would usher in an "American Century," but were not prepared for contingencies of one sort or another.

This pessimism about the claims for American aviation's inherent goodness 


\section{Dominick A. Pisano}

was first voiced by Joseph Corn in The Winged Gospel: America's Romance with Aviation: 1900-1950, first published in 1983 by Oxford University Press. Corn pointed to the treatment of the airplane as an object of reverence (indeed, even worship). In many ways Corn initiated the cultural discussion concerning the representation of aviation when he wrote that "as Americans searched for language appropriate to the excitement they felt for the airplane, they inevitably borrowed from [the] Christian tradition. They often spoke of themselves as 'disciples,' 'apostles,' and 'prophets,' and thought of aviation as a 'winged gospel' or 'holy cause,' one that would literally transform the conditions of life." Corn's hypothesis could well account for the reverential manner in which the history of aviation had been written, at least until recent years. ${ }^{8}$

In the mid-1990s, Leo Marx, in his essay "The Idea of 'Technology' and Postmodern Pessimism," argued convincingly that "a recognition of the central part that the practical arts were expected to play in carrying out the progressive agenda is essential for an understanding of today's growing sense of technological determinism - and pessimism. The West's dominant belief system, in fact, turned on the idea of technological innovation as a primary agent of progress. Nothing in that Enlightenment world-picture prepared its adherents for the shocking series of twentieth-century disasters linked with - and often seemingly caused by - the new technologies.... With the increasingly frequent occurrence of these frightening events since Hiroshima, more and more people in the 'advanced' societies have had to consider the possibility that the progressive agenda, with its promise of limitless growth and a continuing improvement in the conditions of life for everyone, has not been and perhaps never will be realized." 9

Further, Edward Tenner presents a number of case studies of technology's inadvertent ability to "go rogue" and upset the most cherished notions about its intended consequences by producing unintended ones. Tenner cites the example of Capt. Edward Murphy, Jr., USAF, an engineer who realized this bite-back aspect of aviation technology in rocket-sled testing at Muroc Air Force Base (now known as Edwards Air Force Base) in California in the late 1940s: "If there's more than one way to do a job and one of those ways will end in disaster, then somebody will do it that way." This saying has been expressed more concisely as "anything that can go wrong will go wrong"; i.e., the now-colloquial "Murphy's Law."10

And, if one is not convinced by the arguments presented in the books under review, and in the general direction of technological studies away from optimism, or at least toward a more realistic appraisal, you need only to see how much the events of the terrorist attacks ("9/11") on New York and Washington, DC, have (if only subliminally) torn to shreds any arguments that can be made for aviation's beneficence, and, indeed, have reinforced Tenner's ideas about the unintended consequences of technology. ${ }^{11}$

Thus, Empire of the Air, The Jet Sex, and Plane Queer point toward a favorable direction for the "New Aerospace History," the social and cultural history of aviation/space or for whatever newer methodological approaches to the subject may come about. In this regard, Van Vleck sets the stage with a groundbreak- 
ing diplomatic cum social-cultural history of American aspirations to create an aerial empire based primarily on economics, but not without imperial overtones. Vantoch and Tiemeyer expertly play off Van Vleck's themes by examining the cultural issues - mainly gender and labor - that came about as a result of these imperial aspirations. While there has been some gender-based scholarship on women flight attendants, Vantoch's study extends the field to issues of glamour and international competition with Soviet Russia during the Cold War. Tiemeyer's work goes beyond a study of gender by examining unique issues related to male flight attendants, including gayness and AIDS.

These works contribute significantly to the small but growing body of scholarship on aviation in the United States. They are an admirable response to various calls for a revisioned aerospace history, one that takes into account currents in mainstream historical circles and is willing to deal realistically with aviation/spaceflight's role in American culture. Nevertheless, the field has only begun to break new ground. Issues of race, gender and sexuality, and labor need additional examination, as do issues of aviation and foreign policy. As the historiography grows and becomes more sophisticated, studies of aviation/space ideally should become more global and/or transnational and less nationalistic. Military aviation is a subject that begs for new approaches, despite the slowly evolving "New Military History." Questions of aviation technology transfer across international boundaries need to be addressed. These are just a few of the areas ripe for potential scholarship. Although one is reluctant to predict the future of aerospace history, the field will no doubt be influenced by broader trends in historical scholarship.

\section{Notes}

1. Roger D. Launius, "The Historical Dimensions of Space Exploration: Reflections and Possibilities," Space Policy 16 (2000): 23-38. See also, Dominick A. Pisano, "Recent Aerospace Historiography: A Slow but Steady Revolution," in Peter Norton, et al., Mobility in History: Reviews and Reflections, T2M (International Association for the History of Transport, Traffic and Mobility) Yearbook 2012 (Éditions Alphil-Presses universitaires suisses, 2011): 95-102.

2. Launius, 23-28. It is worth mentioning that a good deal of the research for Van Vleck, Vantoch, and Tiemeyer's work was done as a result of the fellowship program at the National Air and Space Museum, Smithsonian Institution, where all three were in residence at various times. This program has provided significant impetus for scholarship in the "New Aerospace History."

3. Wiebe E. Bijker, Thomas P. Hughes, Trevor Pinch (eds.), The Social Construction of Technological Systems: New Directions in the Sociology and History of Technology (Massachusetts Institute of Technology Press. Kindle Edition). In addition to Biejker, et al., see the work of Bruno Latour, Reassembling the Social: An Introduction to Actor-Network Theory, Clarendon Lectures in Management Study (New York: Oxford University Press, 2007) and John Law and John Hassard, eds., Actor Network Theory and After (Hoboken, NJ: Wiley-Blackwell, 1999). On issues of technological determinism, see Merritt Roe Smith and Leo Marx, eds., Does Technology Drive History? The Dilemma of Technological Determinism (Cambridge, MA: Massachusetts Institute of Technology Press, 1995).

4. See Cook and Glickman, "Twelve Propositions for a History of U.S. Cultural History," in James W. Cook, Lawrence B. Glickman, and Michael O’Malley, eds., The Cultural Turn in U.S. History: Past, Present, and Future (Chicago: University of Chicago Press, 2008), 3-57.

5. Vantoch refers to the work of Joanne Meyerowitz, ed., Not June Cleaver: Women and Gender in Postwar America, 1945-1960, Critical Perspectives on the Past (Philadelphia: Temple University Press, 1994) as being especially stimulating for discussions of Cold War gender issues. She also mentions other pivotal works in a scholarly examination of stewardesses: Kathleen Barry, Femininity in Flight: A History of Flight Attendants (Durham, NC: Duke University Press, 2007); 


\section{Dominick A. Pisano}

Drew Whitelegg, Working the Skies: The Fast-Paced Disorienting World of the Flight Attendant (New York: New York University Press, 2007); Christine Yano, Airborne Dreams: "Nisei" Stewardesses and Pan American World Airways (Durham, NC: Duke University Press, 2011); Cathleen Marie Dooley, "Battle in the Sky: A Cultural and Legal History of Sex Discrimination in the United States Airline Industry, 1930-1980" (PhD diss., University of Arizona, 2001); and Suzanne Lee Kolm, "Women's Labor Aloft: A Cultural History of Airline Attendants in the United States, 1930-1978" (PhD diss., Brown University, 1995).

6. McNeil's case never went to court, but was adjudicated by the New York State Commission for Human Rights (NYSCHR).

7. "Stonewall" refers to the riot that took place after the Stonewall Inn, a gay club in New York City, was raided by police on June 28,1969 . This event marks the birth of the Lesbian, Gay, Bisexual, Transexual (LGBT) movement in the US.

8. Joseph J. Corn, The Winged Gospel: America's Romance with Aviation (Baltimore: Johns Hopkins University Press, 2002), xiv.

9. Marx, "The Idea of 'Technology' and Postmodern Pessimism," in Smith and Marx, eds., Does Technology Drive History? The Dilemma of Technological Determinism (Cambridge, MA: Massachusetts Institute of Technology Press, 1995), 240. The disasters that Marx speaks of "since Hiroshima" are the technological disasters of Bhopal, Exxon Valdez, and Three Mile Island, as well as the "national trauma" of the Vietnam War. Since 1995 when the essay was published, Marx could have mentioned the BP oil spill as well as the terrorist attacks on the United States in 2001 (9/11) that employed commercial airliners as weapons.

10. Quoted in Tenner, Why Things Bite Back: Technology and the Revenge of Unintended Consequences (New York: Vintage Books, 1997), 22-23. Some have questioned the origins of "Murphy's Law," citing, for example, the British-derived "Sod's Law"; i.e., "something bad will predictably happen to some unlucky sod." Nevertheless, Murphy is credited with the iteration that concerns technological failure.

11. Before $9 / 11$, aircraft hijacking was a well-known phenomenon internationally. It was especially rampant in the 1970 s and 1980 s with such events as the hijacking of Air France Flight 139 during the 1976 Olympics, the mysterious case of D. B. Cooper (November 24, 1971), which remains unsolved, and the hijacking of Pan American Flight 73 (September 5, 1986). Ordinary aircraft hijackings, however, were nothing compared to the shocking and momentous events of September 11, 2001, when Muslim terrorists flew commercial airliners into the World Trade Center buildings in New York City and the Pentagon in Washington, DC. A third airliner was suspected of being intended for the US Capitol building in Washington, but the attempt was thwarted.

In the aftermath, 9/11's significance as a pivotal moment in the history of aviation has been largely forgotten in the larger context of a daring attack on the United States. This is likewise true of the Japanese attack on Pearl Harbor on December 7, 1941, in which the actual attack by aircraft has been subsumed into the context of a "day of infamy" and the United States' entry into World War II. The point is that the history of aviation does have context, if not contexts, and these contexts are often more significant than the aviation history events that form their crux.

In the case of 9/11, the event has given rise to a host of significances much larger than the actual act of terrorism. First of all, the official version of the events and of those leading up to it has been questioned officially and unofficially. These investigations have failed to quell charges of conspiracy some perhaps legitimate, considering the flaws in the official story, and some downright irrational. Moreover, the events of 9/11 have produced the so-called "War on Terror," characterized by actual wars in Iraq and Afghanistan, and by other events that have been perceived by some as placing severe restrictions on American civil liberties - the Patriot Act of 2001 and a license to use extraordinary measures, even torture (officially, "enhanced interrogation techniques") to obtain information about terrorist threats. 9/11 has also caused what might be termed a "rhetorical" war on terror, in which much of the approved discourse and commemoration that surround the event and its aftermath have tended to confirm and solidify notions of American exceptionalism and other deep-seated ideas of national identity. 